Take 20\% Off All Publications Purchased Directly Through the IGI Global Online Bookstore: www.igi-global.com/

Add to Cart

Available. Instant access upon order completion.

Available In

- Advances in Educational Marketing, Administration, and Leadership

- InfoSci-Books

- InfoSci-Education

- InfoSci-Social Sciences and Humanities

- InfoSci-Select

- InfoSci-Education Knowledge Solutions - Books

- InfoSci-Social Sciences Knowledge Solutions - Books

\title{
Knowledge Sharing Practices, ICT, Information Literacy, and STEM Career Path Choices Among Girls at the Secondary School Level: Girls and STEM Education
}

Mercy A. Iroaganachi (Covenant University, Nigeria), Promise Ifeoma Ilo (Covenant University, Nigeria), Loveth Ekwueme (National Open University of Nigeria, Nigeria) and Idarefame YoungHarry (Rivers State School of Nursing, Nigeria)

Source Title: Women's Influence on Inclusion, Equity, and Diversity in STEM Fields Copyright: (C) 2019 |Pages: 26

DOI: $10.4018 / 978-1-5225-8870-2 . c h 009$

$\$ 30.00$

List Price: $\$ 37.50$

\section{Abstract}

This chapter explored literature and discussed the importance of knowledge sharing practices, ICT, and information literacy, and their influence on STEM career path choices among girls at the secondary school level. This was properly situated by examining the concept of knowledge sharing, concept of career path choices, knowledge sharing on career path choices of girls, considered ICT and career path choices of girls, effect of ICT on career path choices of girls, 
information literacy and career path choices of girls, effect of information literacy on career path choices of girls. It concludes that a culture of knowledge sharing practices among the girls will get the less knowledgeable girls informed for informed STEM career path decisions. The use of ICTs for networking and sharing knowledge among the girls will improve information literacy skills needed by the girls to help identify information needs, access, retrieve, evaluate, and use same career choices. The chapter includes recommendations.

Chapter Preview

$\underline{\text { Top }}$

\section{Background}

Over the years, researchers have engaged in several research and made huge efforts with varied interventions by organizations around the world towards increasing female involvement in (STEM), yet the number of women participation is still very low. UNESCO Institute for Statistics (2015) revealed that female representation is only about $30 \%$ of the total population in STEM while in Africa it is about 17\% (Ekine and Negar, 2013). These statistics raise the question of what could be responsible for the resistant disparity. Could it be that girls at the foundational level do not have adequate career information about STEM and all it entails? What knowledge of STEM career path have been created, documented and being shared among the girls to help them in making right choices?

Career path choices are better made at the early stage of one's educational life as it is the foundation laying for a desired profession. According to (Ekine and Negar, 2013) career path choice ought to be made at the early school level because this is when interests and attitudes about learning are formed. Career choice is a process of choosing a career path which involves choices regarding education and training for a given career (John, Scott, Robert, Gibson, \& Adam (2009). Consequently, decision making is a vital instrument of career choices and it is influenced greatly by a robust knowledge base about different careers that the student has. This engenders interest, desire for self-realization and outcome expectancies upon which career choices are made.

Career choices are difficult decision for students since it determines the kind of profession that they intend to pursue in life. However, provision of experiences that expand the exploration process and a wide range of career information on all the available careers can help students to explore widely before making their choices (Kochung and Migunde, 2011). Hence, persons that offer career advice to students should ensure that students are well informed so as to provide accurate information that will lead to correct career choice. Ferreira and Lima (2010) recommended guidance interventions that will help them acquire knowledge, skills and attitudes that will facilitate better career choices and transitions thereby ameliorating the problem of career choices. In order to achieve this therefore, research revealed peers as having great influence on students' career choices thus, recommending peer training for maximum benefit in knowledge sharing practices among peers (Mtemeri, 2017).

\section{Complete Chapter List}


Search this Book:

Reset

Editorial Advisory Board

View Full PDF

Table of Contents

View Full PDF

Detailed Table of Contents

View Full PDF

Foreword

Shanika N. Robinson

View Full PDF

Preface

Ursula Thomas, Jill Drake

View Full PDF

Chapter 1

Societal Factors and Workplace Perceptions: Understanding Social Determinants of Professional STEM Achievement and Persistence for Black Women (pages 1-21)

Ashley Huderson, Brandy Huderson

Sample PDF

$\$ 37.50$

Chapter 2

Navigating the Landscape of the STEM Professoriate: Reflections and Insights From Women of Color (pages 22-65)

Pamela M. Leggett-Robinson, Brandi Campbell Villa

Sample PDF

$\$ 37.50$

Chapter 3

What Sports Do You Play? Actually, My Major Is Mathematics: Experiencing STEM as a

Woman of African Descent (pages 66-75)

Natasha N. Ramsay-Jordan

$\underline{\text { Sample PDF }}$

$\$ 37.50$

Chapter 4

Overcoming the Layers of Obstacles: The Journey of a Female African American Physicist to

Achieve Equity, Diversity, and Inclusiveness (pages 76-107)

Helen C. Jackson

Sample PDF

$\$ 37.50$

Chapter 5

Creating Support Systems for Black Women in Nontraditional STEM Career Paths (pages 108142)

Tokiwa T. Smith, Natasha N. Johnson

Sample PDF

$\$ 37.50$

Chapter 6

Afro-Caribbean Immigrants in STEM Careers: One Woman's Experience Teaching in a STEM

Field (pages 143-168) 
Beverley-Ann Scott

Sample PDF

$\$ 37.50$

Chapter 7

Grace Under Fire (pages 169-193)

Ursula Thomas, Jill Drake

$\underline{\text { Sample PDF }}$

$\$ 37.50$

Chapter 8

Fortitude: A Study of African Americans in Surgery in New York City (pages 194-226)

Robert S. Kurtz

Sample PDF

$\$ 37.50$

Chapter 9

Knowledge Sharing Practices, ICT, Information Literacy, and STEM Career Path Choices

Among Girls at the Secondary School Level: Girls and STEM Education (pages 227-252)

Mercy A. Iroaganachi, Promise Ifeoma Ilo, Loveth Ekwueme, Idarefame YoungHarry

Sample PDF

$\$ 37.50$

About the Contributors

View Full PDF

Index

View Full PDF

Learn More

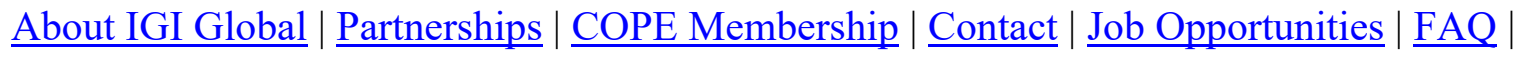

Management Team

Resources For

$\underline{\text { Librarians }}|\underline{\text { Authors/Editors }}| \underline{\text { Distributors }} \mid \underline{\text { Instructors }}$ | Translators | Editorial Services

Media Center

$\underline{\text { Webinars }}|\underline{\text { Blogs }}| \underline{\text { Catalogs }} \mid \underline{\text { Newsletters }}$

Policies

$\underline{\text { Privacy Policy }}|\underline{\text { Cookie \& Tracking Notice }}| \underline{\text { Fair Use Policy } \mid \text { Ethics and Malpractice }}$

Copyright (C) 1988-2020, IGI Global - All Rights Reserved 